\title{
Asymptomatic Bacteriuria Bacterial Profile and Antibiotic Susceptibility Pattern Among Pregnant Women Attending Antenatal Care (Anc) Clinic of Assosa General Hospital, Benishangul Gumuz Region, Western Ethiopia
}

Duresa Abu Tusuna ( $\nabla$ dura2002@gmail.com )

Assosa University https://orcid.org/0000-0001-9680-211X

Teferra Abula Orjino

Addis Ababa University

Research

Keywords: Asymptomatic Bacteriuria, Antimicrobial Susceptibility, Pregnant Women, Antibiotic resistance

Posted Date: November 4th, 2020

DOI: https://doi.org/10.21203/rs.3.rs-100055/v1

License: (c) (i) This work is licensed under a Creative Commons Attribution 4.0 International License. Read Full License 


\section{Abstract}

Background: ASB is a common problem in pregnant women and about $40 \%$ of women with untreated asymptomatic bacteriuria during pregnancy develop pyelonephritis, which might lead to low birth weight, preterm, premature rupture of membranes and preterm labour. Therefore, this study aimed to assess the prevalence of asymptomatic bacteriuria, antimicrobial susceptibility pattern of the isolates among pregnant women attending antenatal care clinic of Assosa General Hospital, western Ethiopia.

Methods: A facility-based cross sectional study was conducted from January to February 2019. Well-mixed and uncentrifuged urine specimens obtained from the pregnant women was directly inoculated on cystine lactose electrolyte deficient agar (CLED) (Oxoid, Ltd, England) media by streak plate method. Bacterial isolates were identified as per the standard bacteriological procedure using colony characteristics, gram-staining, and series of biochemical tests. Antimicrobial susceptibility test was carried out by Kirby- Bauer disk diffusion technique on Muller-Hinton agar medium and the diameter of zone of inhibition was interpreted according toClinical Laboratory Standard Institute (CLSI) guidelines

Result: The overall prevalence of ASB among pregnant women in this study was $14.85 \%$.E. coli was the most predominant isolate $(50 \%$ ) followed by K. pneumoniae $(16.7 \%)$, S. aureus (14.3\%), coagulase negative staphylococci (CONS) (11.9\%), and group B streptococci (GBS) (7.1\%).Gram-negative bacteria were highly resistant for tetracycline (96.4\%), ampicillin .Gram-positive bacteria were $100 \%$ sensitive for ceftazidime.

Conclusion: Significant bacteriuria was observed in asymptomatic pregnant women. Therefore, routine laboratory diagnosis of ASB in pregnant women and providing appropriate treatment should be needed to reduce its complications.

\section{Background}

Asymptomatic bacteriuria (ASB) is defined as the presence of $10^{5}$ and more colony forming units (CFU) per milliliter $(\mathrm{mL})$ of urine in the absence of specific symptoms of acute UTIs $(1,2)$. Pregnant women are at increased risk of asymptomatic bacteriuria due to mechanical factors, hormonal changes, urinary stasis and reflux of urine from bladder to ureters(3). Therefore, screening for bacteriuria during pregnancy irrespective of whether patient is symptomatic or not is important in first care setting as early treatment can prevent subsequent complications(4,5).Both Gram-negative and positive bacteria are predominantly responsible from ASB during pregnancy[1]. Screening for asymptomatic bacteriuria became standard obstetric care, and most antenatal guidelines today include routine screening for asymptomatic bacteriuria. The United States Preventive Services Task Force strongly recommends screening and treatment, and similar recommendations are included in guidelines from Infectious Diseases Society of America, the National Institute for Clinical Excellence, the European Association of Urology, the Canadian Task Force on Preventive Care, and most recently from the Scottish Intercollegiate Guidelines Network.[6-11]. Even if Standard Treatment Guidelines in Ethiopia recommend screening and treatment of ASB, Unfortunately, screening and treatment of pregnant women for asymptomatic bacteriuria never became standard ANC follow-up practice in Ethiopia. Du to In most developing countries including Ethiopa the limited health care budgets and lack adequate laboratory facil-ities or trained microbiologists or both afectes the health care system a lot. $(12,13)$.At the sometime Antimicrobial resistance in bacteriuria is increasing worldwide and some bacteria are virulent and capable of acquiring multidrug resistance to antimicrobials. Rates of antimicrobial resistance vary according to geographic locations and they are directly proportional to the use and misuse of antimicrobials. Du to this Antimicrobial therapy of a pregnant woman is a serious concern during pregnancy. Deferent studies show deferent resistance pattern. However, there was lack of data on the prevalence of ASB and antimicrobial susceptibility of the bacterial isolates among pregnant women in Benishangul Gumuz Region,Ehiopia.. Therefore, this study was aimed to assess the prevalence of asymptomatic bacteriuria, antimicrobial susceptibility pattern of the bacterial isolates and related risk factors among pregnant women attending antenatal care (ANC) clinic of Assosa General Hospital, Western Ethiopia.

\section{Materials And Method}

This study was conducted at Assosa General Hospital from January to February, 2019. The hospital is found in Assosa town and the town is $670 \mathrm{~km}$ away from the capital city of Ethiopia, Addis Ababa in Western part of the country.All pregnant women attending the ANC clinic of Assosa General Hospital for ANC services and pregnant women without signs and symptoms of UTIs was included consecutively as study subjects. After taking written informed consent from the pregnant women, About $5 \mathrm{~mL}$ of 
freshly voided midstream urine samples were collected from each study participant using a sterile screw-capped, wide-mouth container and the urine samples Culture plates were incubated in the aerobic environment at $37^{\circ} \mathrm{C}$ for $24-48 \mathrm{hrs}$ and following overnight incubation plates were checked for growth. All plates with $10^{5}$ and more bacterial colonies per milliliter ( $\mathrm{ml}$ ) of urine were sub-cultured on to MacConkey agar (Oxoid, England), and 5\% sheep blood agar (Oxoid, England) for further identification. Bacterial isolates were identified as per the standard bacteriological procedure using colony characteristics, gram-staining, and series of biochemical tests. Antimicrobial susceptibility test was carried out by Kirby-Bauer disk diffusion technique on Muller-Hinton agar medium and the diameter of zone of inhibition was interpreted according to Clinical Laboratory Standard Institute (CLSI) guidelines. About 3-5 pure bacterial colonies were suspended in normal saline and mixed smoothly until 0.5 McFarland standards were reached. By using sterile swab, the prepared standard suspension was evenly swabbed onto the surface of Muller-Hinton agar and the inoculated plates were stored at room temperature for 3-5minutes to allow the medium to absorb the moisture from the inoculums and will be dried by placing the plates in incubators at $35-36.5^{\circ} \mathrm{C}$. The antibiotic discs were placed at equal distance to the dried Muller-Hinton agarmedia containing the inoculated bacteria and were incubated at $37^{\circ} \mathrm{C}$ for $18-24 \mathrm{hrs}$ and the diameter of zone of inhibition around the disc was measured and interpreted according to CLSI.

\section{Ethical consideration}

The study was ethically approved by Ethical review board of Addis Ababa University College of Health Sciences, School of pharmacy (ERB). Official permission was obtained from Benishangul Gumuz Region Health Bureau and from Assosa General Hospital administrative bodies. During data collection, each study participant was informed about the purpose of the study and written informed consent obtained from the pregnant mothers. Anyone who was not willing to participate in the study was excluded from the study. Any information concerning the study participants kept confidential and the specimen collected from the study participants was only analyzed for the intended purposes. Pregnant women who had significant bacteriuria received appropriate treatment according to the national guideline.

Operational Definitions

\section{Asymptomatic UTI (ASB)}

It is the presence of significant bacteria $\left(\geq 10^{5} \mathrm{cfu} / \mathrm{ml}\right)$ in a patient without signs or symptoms of UTI.

\section{Midstream urine}

A specimen obtained from the middle part of urine flow.

\section{Multidrug resistance}

is antimicrobial resistance shown by a species of microorganism to three or more antibiotics of different classes.

\section{Result And Discussion}

A total of 283 pregnant mothers without signs and symptoms of UTI were included in this study. The prevalence of ASB among pregnant women in this study was $14.85 \%(n=42 / 283)$. In this study, gram- negative bacteria $(66.7 \%)$ were more prevalent than gram- positive bacteria (33.4\%). (Fig. 1) which are consistent with other studies done in Adigrat Northern Ethiopia (64.1\%) [14]. and studies done in Nairobi Kenya (78.8\%) [15], central region of Iran (69.6\%) [16] and Bengal India(62.3\%) [17]. This might be due to the fact that most uropathogenic bacteria in pregnant women are gram negative that usually originate from the bowel and ascend to the upper urinary tract due to the close proximity of female urethra to the anal area. In addition, during pregnancy difficulties in cleaning genital area during defecation might result in contamination of female urinary tract with fecal bacteria (mostly gramnegative). However, our finding is in contrary to studies done in Dessie Northeast Ethiopia [18], Hawassa Southern Ethiopia [19], which reported the predominance of gram-positive bacteria over gram-negative bacteria among pregnant women with ASB. The possible explanation for this discrepancy might be due to differences in environmental conditions such as temperature and humidity between these different study areas and differences in the level of antimicrobial usage by patients among these different 
study sites, all of which could affect the distribution of bacteria in different countries and among different regions in the same country

. Regarding bacterial species, E. coli (50\%) was the predominant bacterial isolates observed in this study followed by K. pneumonia (16.7\%), S. aureus (14.3\%), CoNS (11.9\%) and GBS (7.1\%). (Fig. 1). The predominance of E. coli in our study is consistent with studies done in Bahir Dar Northwest Ethiopia [21], Hawassa Southern Ethiopia [20] and studies done in Ghana [22], Egypt [23] and India [18].The acquired ability of E. coli to produce a number of virulence factors that facilitate colonization and invasion of the urinary epithelium might be one possible explanation for the predominance of E. coli in pregnant women with ASB [24]. Regarding the antimicrobial susceptibility pattern of bacterial uropathogens, the finding of our study showed that bacterial uropathogens isolated from pregnant women with asymptomatic UTI develop resistant to commonly used antimicrobial agents. In this study, Most of the Gram-negative bacterial isolates were sensitive to meropenem (96.4\%), ceftazidm (85.7\%), while were highly resistant for tetracycline (96.4\%), ampicillin (92.9\%), (Table 1). Our finding is in line with studies done in Dessie Northeast Ethiopia [24], Baghdad, Iraq [25], and Kanpur, India[26]. Which show that most of the Gram-negative isolates were sensitive to ceftazidm, ceftriaxone, cefotaxime, amikacin, tobramycin and ciprofloxacin and resistant to tetracycline and amoxicillin. However, our finding is in contrary to studies done in Kashmir [27], and Adigrat Northern Ethiopia [28]. Which show that most of the Gram-negative isolates were sensitive trimethoprim-sulfamethoxazole augmentin, nalidixic acid and gentamycin. The easy accessibility of the commonly prescribed antimicrobials over-the counter combined with the misuse of the antibiotics by both patients and clinicians due to lack of facilities and trained personnel for urine culture in most health facilities in Ethiopia and frequent use of common antimicrobial agents by peoples without prescription or medical supervision might be responsible for the observed high prevalence of antimicrobial resistance to commonly used antibiotics. Increased resistance of E. coli to $\beta$-lactamase inhibitors combined with the emergence of extended spectrum $\beta$-lactamase (ESBL) inhibitors (meropenem) resistant E. coli isolates (4\%) in this study area is a worrying situation that needs continuous monitoring and surveillance of antimicrobial resistance of E. coli mainly in highly vulnerable groups such as pregnant women.

The finding of our study also showed that Gram-positive bacterial isolates were highly resistant for tetracycline (100\%), trimethoprim-sulfamethoxazole (78.6\%), penicillin (71.4\%), augmentin (75\%) and nalidixic acid (57.1\%).(Table 2) Relatively similar resistance rates of Gram-positive isolates for these antibiotics are also reported from studies done in, Gondar Northwest Ethiopia [29], and India [18] which might be due to the indiscriminate and misuse of the antibiotics for empirical therapy. In this study, most of Gram-positive bacteria isolates were sensitive for ceftazidime (100\%), vancomycin $(92.9 \%)$, clindamycin $(92.9 \%)$, tobramycin(85.7\%),chloramphenicol (78.6\%), norfloxacillin (70.4\%), ciprofloxacin(64.3\%) and erythromycin (64.3\%). Relatively similar susceptibility rate of Gram-positive isolate to most of these antimicrobial agents are reported from studies done in Adama Central Ethiopia [15].which might be due to the relative inaccessibility of these antibiotics over the counter.

In this study, multi drug resistance (MDR = resistance in $\geq 3$ drugs) was seen in $76.2 \%$ of the isolated bacterial uropathogens. Our finding is higher than studies done in Dessie Northeast Ethiopia (72.4\%) [19], Tikur Anbessa Specialized Hospital Addis Ababa (74\%) [30]. The high prevalence of MDR reported in this study might be due to the unrestricted availability and high rate of use of prescribed drugs. It could also be related to the rapid spread of resistant bacteria and high misuse of antimicrobial drugs such as self-medication, unnecessary use, failure to adhere to standard treatment guideline, lack of appropriate infection prevention strategies and inadequate or absence of antimicrobial drug resistance surveillance program. 
Table 1

Antimicrobial susceptibility pattern of gram-negative bacteria isolated from the urine of pregnant women

\begin{tabular}{|c|c|c|c|c|c|c|c|c|c|c|c|c|c|c|}
\hline \multirow{2}{*}{$\begin{array}{l}\text { Bacterial isolates } \\
\text { (no.) }\end{array}$} & & \multicolumn{13}{|c|}{ Antimicrobial agents tested } \\
\hline & & TER & NA & CIP & SMT & GEN & AMK & TOB & AMP & $\begin{array}{l}\text { AMX- } \\
\text { C }\end{array}$ & CEF & CTX & CAZ & MER \\
\hline \multirow[t]{4}{*}{ E. coli $(n=21)$} & $S$ & 1 & 9 & 14 & 5 & 10 & 18 & 21 & 2 & 5 & 15 & 16 & 17 & 20 \\
\hline & & 4.8 & 42.9 & 66.6 & 23.8 & 47.6 & 85.7 & 100 & 9.5 & 23.8 & 71.4 & 76.2 & 81 & 95.2 \\
\hline & $\mathrm{R}$ & 20 & 12 & 7 & 16 & 11 & 3 & 0 & 19 & 16 & 6 & 5 & 4 & 1 \\
\hline & & 95.2 & 57.1 & 33.4 & 76.2 & 52.4 & 14.3 & 0 & 90.5 & 76.2 & 28.6 & 23.8 & 19 & 4.8 \\
\hline \multirow[t]{4}{*}{ K. pneumonia(7) } & $S$ & 0 & 2 & 2 & 0 & 2 & 3 & 3 & 0 & 2 & 3 & 2 & 7 & 7 \\
\hline & & 0 & 28.6 & 28.6 & 0 & 28.6 & 42.9 & 42.9 & 0 & 28.6 & 42.9 & 28.6 & 100 & 100 \\
\hline & $\mathrm{R}$ & 7 & 5 & 5 & 7 & 5 & 4 & 4 & 7 & 5 & 4 & 5 & 0 & 0 \\
\hline & & 100 & 71.4 & 71.4 & 100 & 71.4 & 57.1 & 57.1 & 100 & 71.4 & 57.1 & 71.4 & 0 & 0 \\
\hline \multirow[t]{4}{*}{ Total $(\mathrm{n}=28)$} & $S$ & 1 & 11 & 16 & 5 & 12 & 21 & 24 & 2 & 7 & 18 & 18 & 24 & 27 \\
\hline & & 3.6 & 39.3 & 57.1 & 17.9 & 42.9 & 75 & 85.7 & 7.1 & 25 & 64.3 & 64.3 & 85.7 & 96.4 \\
\hline & $\mathrm{R}$ & 27 & 17 & 12 & 23 & 16 & 7 & 4 & 26 & 21 & 10 & 10 & 4 & 1 \\
\hline & & 96.4 & 60.7 & 42.9 & 82.1 & 57.1 & 25 & 14.3 & 92.9 & 75 & 35.7 & 35.7 & 14.3 & 3.6 \\
\hline
\end{tabular}

Table 2. Antimicrobial susceptibility pattern of gram-positive bacteria isolated from the urine of pregnant women 


\begin{tabular}{|c|c|c|c|c|c|c|c|c|c|c|c|c|c|}
\hline \multirow{2}{*}{$\begin{array}{l}\text { Bacterial } \\
\text { isolates } \\
\text { (no.) }\end{array}$} & \multicolumn{13}{|c|}{ Antimicrobial agents tested } \\
\hline & & CLI & ERY & CAF & PE & CAZ & NA & TOB & CIP & STX & NOR & VAN & TET \\
\hline \multirow[t]{2}{*}{$\begin{array}{l}\text { S. } \\
\text { aureus(6) }\end{array}$} & $S$ & $\begin{array}{l}6 \\
(100)\end{array}$ & $\begin{array}{l}4 \\
(66.7)\end{array}$ & $\begin{array}{l}5 \\
(83.3)\end{array}$ & $\begin{array}{l}1 \\
(16.7)\end{array}$ & $\begin{array}{l}6 \\
(100)\end{array}$ & $\begin{array}{l}3 \\
(50)\end{array}$ & $\begin{array}{l}6 \\
(100)\end{array}$ & $\begin{array}{l}4 \\
(66.7)\end{array}$ & $\begin{array}{l}1 \\
(16.7)\end{array}$ & $\begin{array}{l}5 \\
(83.3)\end{array}$ & $\begin{array}{l}5 \\
(83.3)\end{array}$ & $\begin{array}{l}0 \\
(0)\end{array}$ \\
\hline & $\mathrm{R}$ & $\begin{array}{l}0 \\
(0)\end{array}$ & $\begin{array}{l}2 \\
(33.3)\end{array}$ & $\begin{array}{l}1 \\
(16.7)\end{array}$ & $\begin{array}{l}5 \\
(83.3)\end{array}$ & $\begin{array}{l}0 \\
(0)\end{array}$ & $\begin{array}{l}3 \\
(50)\end{array}$ & & $\begin{array}{l}2 \\
(33.3)\end{array}$ & $\begin{array}{l}5 \\
(83.3)\end{array}$ & $\begin{array}{l}1 \\
(16.7)\end{array}$ & $\begin{array}{l}1 \\
(16.7)\end{array}$ & $\begin{array}{l}6 \\
(100)\end{array}$ \\
\hline \multirow[t]{2}{*}{ CoNS (5) } & $S$ & $\begin{array}{l}4 \\
(80)\end{array}$ & $\begin{array}{l}3 \\
(60)\end{array}$ & $\begin{array}{l}4 \\
(80)\end{array}$ & $\begin{array}{l}2 \\
(40)\end{array}$ & $\begin{array}{l}5 \\
(100)\end{array}$ & $\begin{array}{l}2 \\
(40)\end{array}$ & $\begin{array}{l}4 \\
(80)\end{array}$ & $\begin{array}{l}3 \\
(60)\end{array}$ & $\begin{array}{l}1 \\
(20)\end{array}$ & $\begin{array}{l}3 \\
(60)\end{array}$ & $\begin{array}{l}5 \\
(100)\end{array}$ & $\begin{array}{l}0 \\
(0)\end{array}$ \\
\hline & $\mathrm{R}$ & $\begin{array}{l}1 \\
(20)\end{array}$ & $\begin{array}{l}2 \\
(40)\end{array}$ & $\begin{array}{l}1 \\
(20)\end{array}$ & $\begin{array}{l}3 \\
(60)\end{array}$ & $\begin{array}{l}0 \\
(0)\end{array}$ & $\begin{array}{l}3 \\
(60)\end{array}$ & $\begin{array}{l}1 \\
(20)\end{array}$ & $\begin{array}{l}2 \\
(40)\end{array}$ & $\begin{array}{l}4 \\
(80)\end{array}$ & $\begin{array}{l}2 \\
(40)\end{array}$ & $\begin{array}{l}0 \\
(0)\end{array}$ & $\begin{array}{l}5 \\
(100)\end{array}$ \\
\hline \multirow[t]{2}{*}{ GBS(3) } & $S$ & $\begin{array}{l}3 \\
(100)\end{array}$ & $\begin{array}{l}2 \\
(66.7)\end{array}$ & $\begin{array}{l}2 \\
(66.7)\end{array}$ & $\begin{array}{l}1 \\
(33.3)\end{array}$ & $\begin{array}{l}3 \\
(100)\end{array}$ & $\begin{array}{l}1 \\
(33.3)\end{array}$ & $\begin{array}{l}2 \\
(66.7)\end{array}$ & $\begin{array}{l}2 \\
(66.7)\end{array}$ & $\begin{array}{l}1 \\
(33.3)\end{array}$ & $\begin{array}{l}2 \\
(66.7)\end{array}$ & $\begin{array}{l}3 \\
(100)\end{array}$ & $\begin{array}{l}0 \\
(0)\end{array}$ \\
\hline & $\mathrm{R}$ & $\begin{array}{l}0 \\
(0)\end{array}$ & $\begin{array}{l}1 \\
(33.3)\end{array}$ & $\begin{array}{l}1 \\
(33.3)\end{array}$ & $\begin{array}{l}2 \\
(66.7)\end{array}$ & $\begin{array}{l}0 \\
(0)\end{array}$ & $\begin{array}{l}2 \\
(66.7)\end{array}$ & $\begin{array}{l}1 \\
(33.3)\end{array}$ & $\begin{array}{l}1 \\
(33.3)\end{array}$ & $\begin{array}{l}2 \\
(66.7)\end{array}$ & $\begin{array}{l}1 \\
(33.3)\end{array}$ & $\begin{array}{l}0 \\
(0)\end{array}$ & $\begin{array}{l}3 \\
(100)\end{array}$ \\
\hline \multirow[t]{2}{*}{ TOTAL(14) } & $S$ & $\begin{array}{l}13 \\
(92.9)\end{array}$ & $\begin{array}{l}9 \\
(64.3)\end{array}$ & $\begin{array}{l}11 \\
(78.6)\end{array}$ & $\begin{array}{l}4 \\
(28.6)\end{array}$ & $\begin{array}{l}14 \\
(100)\end{array}$ & $\begin{array}{l}6 \\
(42.9)\end{array}$ & $\begin{array}{l}12 \\
(85.7)\end{array}$ & $\begin{array}{l}9 \\
(64.3)\end{array}$ & $\begin{array}{l}3 \\
(21.4)\end{array}$ & $\begin{array}{l}10 \\
(71.4)\end{array}$ & $\begin{array}{l}13 \\
(92.9)\end{array}$ & $\begin{array}{l}0 \\
(0)\end{array}$ \\
\hline & $\mathrm{R}$ & $\begin{array}{l}1 \\
(7.1)\end{array}$ & $\begin{array}{l}5 \\
(35.7)\end{array}$ & $\begin{array}{l}3 \\
(21.4)\end{array}$ & $\begin{array}{l}10 \\
(71.4)\end{array}$ & $\begin{array}{l}0 \\
(0)\end{array}$ & $\begin{array}{l}8 \\
(57.1)\end{array}$ & $\begin{array}{l}2 \\
(14.3)\end{array}$ & $\begin{array}{l}5 \\
(35.7)\end{array}$ & $\begin{array}{l}11 \\
(78.6)\end{array}$ & $\begin{array}{l}4 \\
(29.6)\end{array}$ & $\begin{array}{l}1 \\
(7.1)\end{array}$ & $\begin{array}{l}14 \\
(100)\end{array}$ \\
\hline
\end{tabular}

\section{Conclusion}

E. coli was the most predominant bacterial isolate followed by K. pneumoniae, S. aureus, CONS and GBS. A large number of the bacterial isolates were resistant to the commonly used antimicrobial drugs (tetracycline, ampicillin, trimethoprim-sulfamethoxazole and augmentin) but were sensitive to ceftazidime, clindamycin, cefotaxime and meropenem. The prevalence of MDR bacterial isolates among pregnant women with ASB in this study area was high. Therefore, routine laboratory diagnosis of ASB in pregnant women and providing appropriate treatment should be needed to reduce its complications. In addition, since antibiotic resistance complicates empirical regimens, local resistance rates need to be taken into consideration when deciding on therapy.

\section{Limitations}

The cross sectional nature of the study which makes testing of an association difficult is one of the main limitations of the study. Due to final constraints, we were unable to determine the antimicrobial susceptibility of some important antimicrobial agents such as nitrofurantoin and fosfomycin.

\section{Abbreviations}

$\mathrm{ABU}$

Asymptomatic Bacteriuria ;AMR:Antimicrobial resistance;ANC:Antenatal Care;ASB:Asymptomatic Bacteriuria;AST:Antimicrobial Susceptibility Test; CFU:Colony Forming Unit CoNS:Coagulase Negative Staphylococci; Cl:Confidence Interval;

CLED:CysteineLactose Electrolyte Deficient; CLSI:Clinical Laboratory Standard Institute; E. coli:Escherichia Coli; GBS:Group B 
Streptococcus; MDR:Multidrug resistance; MHA:Muller Hinton Agar; NCCLS:National Committee for Clinical Laboratory Standard;OR:Odds Ratio; RPM:Revolutions per Minute; UTI:Urinary Tract Infection

\section{Declarations}

\section{Acknowledgements}

We thank health workers of Assosa general Hospital staffs for their active cooperation during sample collection. We would like to extend our heartfelt thanks and appreciation to the study participants.

\section{Funding}

This study was fully supported by Addis Ababa Universit, Addis Ababa, Ethiopia and Assosa University, Assosa, Ethiopia. The sponsor of the study had no role in the study design, data collection, data analysis or interpretation, but did review this report prior to submission for publication. The corresponding author had full access to all data in the study and had final responsibility for the decision to submit for publication.

\section{Availability of data and materials}

All the data supporting the finding is contained within the manuscript, no additional data is needed.

\section{Authors' contributions}

Duresa design \& co-directed the project, bacteria isolation, antimicrobial susceptibility and prepared the manuscript. Prof. tefera assisted the design, data analysis \& manuscript preparation. both authors read and approved the final version of the manuscript.

\section{Ethics approval and consent to participate}

An ethical clearance to conduct the study was obtained from Addis Ababa University prior to data collection. Participants were given a full right to continue or withdraw from the study i.e., informed consent was obtained from the study participants by health personnel. All study records that identify subjects were kept confidential and used solely for the purpose of the study. All study participants used to collect information in this study were given code numbers and no names were recorded.

\section{Consent for publication}

Not applicable.

\section{Competing interests}

The authors declare that they have no competing interests.

\section{Author details}

1* College of Health Sciences, Department of midwifery, Assosa University, Ethiopia.

2 Department of Pharmacology and Clinical Pharmacy, Addis Ababa University, Addis Ababa, Ethiopia

\section{References}

1. Ali,Gizachew. M. Asymptomatic bacteriuria and antimicrobial susceptibility pattern of the isolates among pregnant women attending dessie referral hospital , Northeast Ethiopia: a hospital-based cross-sectional study. Turk J Urol 2018;44(3):251-60.

2. South Australian Maternal, Neonatal \& Gynaecology Community of practiceurologic; Clinics of North America. 2017;1-10

3. Jojan J, Davane.M, Patil CD, Nagoba B. Asymptomatic bacteriuria in pregnant women from rural area of latur district of maharashtra India.Journal of Krishna Institute of Medical Sciences University 2017;6(3):48-54. 
4. Bayati AH, Ghaib AH, Nasraldeen N, Hamalaw SA, Hamid ZA. Asymptomatic bacteriuria among pregnant women in sulaimani city. G.J.B.B.2016;5(3):327-30.

5. Mwei MK. Asymptomatic bacteriuria among pregnant women attending antenatal clinic at kilimanjaro christian medical centre in northern tanzania. Clin. Pract 2018;15:917-22.

6. US Preventive Services Task Force (USPSTF). Screening for asymptomatic bacteriuria: recommendation statement. Rockville (MD): Agency for Healthcare Research and Quality (AHRQ), 2004.

7. Nicolle LE, Bradley S, Colgan R et al. Infectious diseases society of America guidelines for the diagnosis and treatment of asymptomatic bacteriuria in adults. Clin Infect Dis 2005; 40: 643-654.

8. National Collaborating Centre for Women's and Children's Health. Clinical Guideline 6. Antenatal Care. Routine care for the healthy pregnant woman. London: National Institute for Clinical Excellence,2003.

9. Naber KG, Bergman B, Bishop MC et al. EAU guidelines for the management of urinary and male genital tract infections. Urinary Tract Infection (UTI) Working Group of the Health Care Office ( $\mathrm{HCO}$ ) of the European Association of Urology (EAU). Eur Urol 2001; 40: 576-588

10. Nicolle LE. Screening for asymptomatic bacteriuria in pregnancy. In Canadian guide to clinical preventive health care. Ottawa: Health Canada, 1994, p100-106

11. Scottish Intercollegiate Guidelines Network. Management of suspected bacterial urinary tract infection in adults. A national clinical guideline. Edinburgh: Scottish Intercollegiate Guidelines Network, July 2006.

12. Mageto, Vincent Mogaka Gatwiri, Mathenge Scholastica Njoroge, wachukahospital r. Uropathogens antibiotic resistance patterns among type 2 diabetic patients in kisii teaching and referral hospital, kenya. Pan African Medical Journal 2018;8688:1-5.

13. Larsen B, Monif . Understanding the bacterial flora of the female genital tract. Clinical Infectious Diseases, 2001;4198:69-77.

14. Abdul Kairun Nisha, Alemayehu Edossa Etana and Hailemichael Tesso. prevalence of asymptomatic bacteriuria during pregnancy in adama city, ethiopia international journal of microbiology and immunology research. 2015;3(5), 058-063

15. Adelaide,Ogutu A \& Gideon K, Christine B, Samuel K. college prevalence aetiology and antibiotic sensitivity profile of asymptomatic bacteriuria isolates from pregnant women in selected antenatal clinic from nairobi, kenya the pan african medical journal. 2017;26:41

16. Aliasghar Farazia, Mansooreh Jabbariasl B. a asymptomatic bacteriuria in pregnancy in the central region of iran: frequency, risk factors, and causative organisms clinical epidemiology and global health, 2018;.09; 009.

17. Kheya Mukherjee, Saroj Golia, Vasudha, Babita, Debojyoti Bhattacharjee, Goutam Chakroborti. a study on asymptomatic bacteriuria in pregnancy: prevalence, etiology and comparison of screening methods Bengal, India international journal of research in medical sciences. 2014;(2)3:1087

18. Ismail Ebrie Ali, Teklay Gebrecherkos, Mucheye Gizachew,Martha Alemayehu Menberu, asymptomatic bacteriuria and antimicrobial susceptibility pattern of the isolates among pregnant women attending dessie referral hospital, northeast ethiopia: a hospital-based cross-sectional study, turk j urol 2018; 44(3): 251-60

19. Tadesse $E$, Teshome M, Merid $Y$, Kibret B, Shimelis T. Asymptomatic urinary tract infection among pregnant women attending the antenatal clinic of hawassa referral hospital , southern Ethiopia. BMC Research Notes. 2014;7:155

20. Jyoti J, Milind Davane, Chandrakala Dawle,Basavraj Nagob. asymptomatic bacteriuria in pregnant women from rural area of latur district of maharashtra, india journal of Clinical and Diagnostic Research.2017; 6:3

21. Tazebew Demilie1, getenet beyene2, selabat melaku3, wondewosen tsegaye* 2 urinary bacterial profile and antibiotic susceptibility pattern among pregnant women in north west ethiopia ethiop j health sci. Vol. 22, no. 2 july 2012

22. A. Turpin, Bridget Minkah, K.A. Danso, and E.H. Frimpong. asymptomatic bacteriuria in pregnant women at- tending antenatal clinic at komfo anokye teach- ing hospital, kumasi, ghana ghana medical journal.2007;41:1

23. Elzayat MA,Barnett-Vanes A, Farag M, Dabour E, Cheng F. Prevalence of undiagnosed asymptomatic bacteriuria and associated risk factors during pregnancy : a cross-sectional study at two tertiary centres in cairo , egypt. 2017;1-7.

24. Lavigne JP, Boutet-Dubois, Laouini, Combescure, Bouziges, Mares, and Sotto. Virulence potential of e. Coli strains causing asymptomatic bacteriuria during pregnancy. J clinmicrobiol.2011;49(11):3950-3 
25. Ali Hattem Bayati, Avan Hussain Ghaib, Narmeen Nasraldeen, Soran Amin Hamalaw \& Zainab A. Hamid Asymptomatic bacteriuria among pregnant women in sulaimani city. g.j.b.b.2016: 5 (3)327-330

26. Ujatha R, Nawan M. Prevalence of asymptomatic bacteriuria and its antibacterial susceptibility pattern among pregnant women attending the antenatal clinic at kanpur, India. J Clin Diagn Res. 2014;8(4):01-3.

27. Shamweel Ahmad, Shehla Shakooh, Sajad Ahmad Salati, Abdul Muniem prevalence of asymptomatic bacteriuria among pregnant women in kashmir sri lanka journal of obstetrics and gynaecology 2011; 33: 158-162

28. Tadesse S, Kahsay T, Adhanom G, Kahsu G, Legese H, Aderajew G. Prevalence, antimicrobial susceptibility profile and predictors of asymptomatic bacteriuria among pregnant women in adigrat general hospital, northern ethiopia. Bmc res notes . 2018;1-6.

29. Alemu A. et al. Bacterial profile and drug susceptibility pattern of urinary tract infection in pregnant women at university of gondar teaching hospital, northwest ethiopia. Bmc res notes. 2012;5:197

30. Assefa A, Asrat D, Woldeamanuel Y, G/Hiwot Y, Abdella A, Melesse T. Bacterial profile and drug susceptibility pattern of urinary tract infection in pregnant women at Tikur Anbessa Specialized Hospital Addis Ababa, Ethiopia. Ethiop Med J 2008;46:227-

\section{Figures}

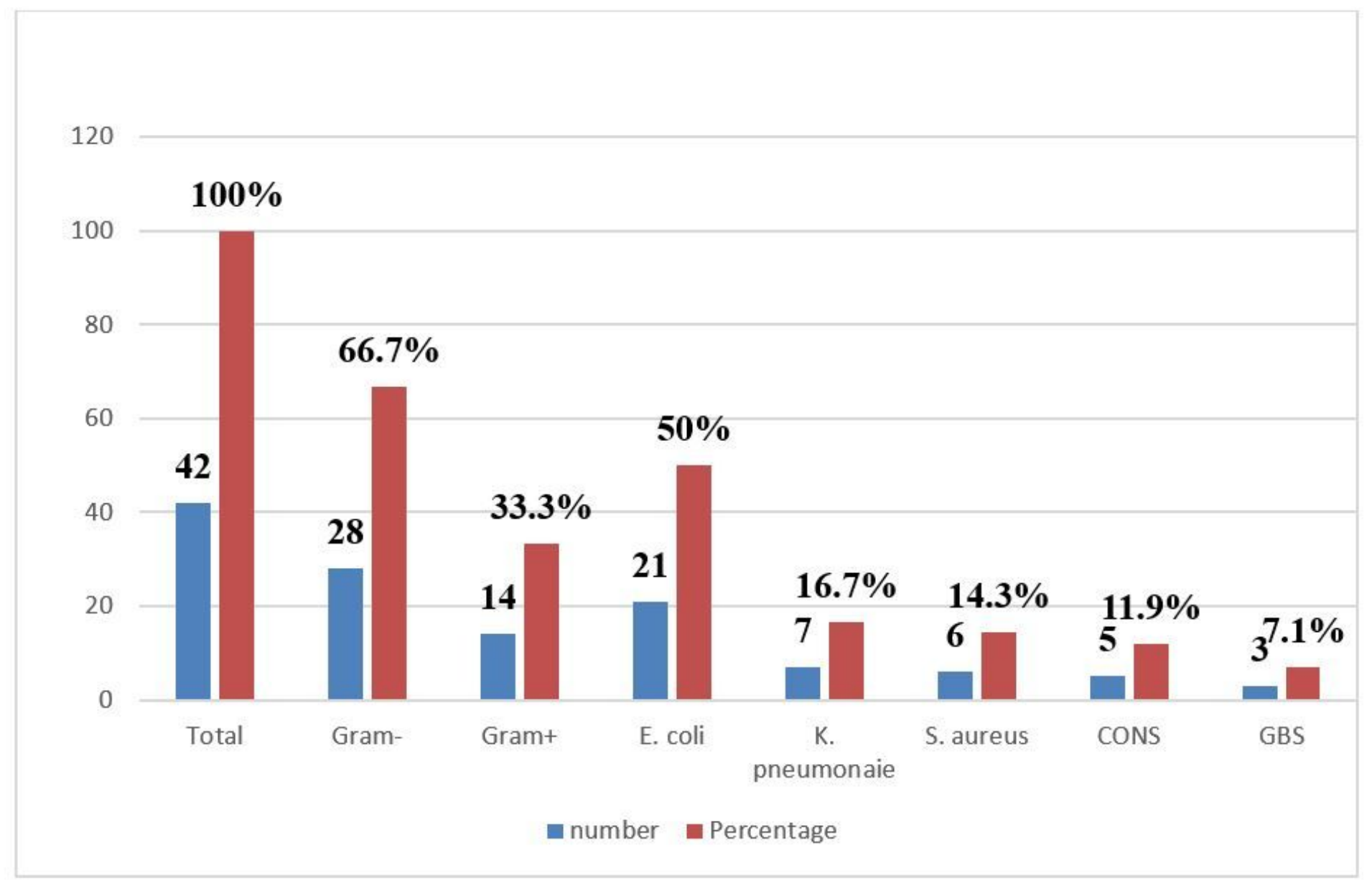

\section{Figure 1}

Frequency of bacterial uropathogens isolated from pregnant women 